\title{
Deletion of Segments in Jussive Verbs: Generative Phonology View
}

\author{
Atef Mustafa Jalabneh \\ Department of English, King Khalid University, Abha, Saudia Arabia \\ Email: dratefj@hotmail.com
}

\begin{abstract}
The objectives: this research is meant to find correct phonological solutions to the deleted and reduced segments at the underlying level of jussive verbs in Modern Standard Arabic. The methodology: to account for any phonological change in jussive, the researcher refers to Chomsky's and Halle's (1968) theoretical views on Generative Phonology. The results: the lax vowels [u \& a] are deleted in jussive verbs if they are followed either by a consonant in one environment and the lax vowel [a] in another. The vowels [a, $\overline{\mathbf{u}}$ $\& \bar{i}$ ] are reduced if followed by a consonant and the lax vowel [a] of the definite article $a l$ 'the'. The conclusions: it is evident that the deletion and reduction of segments are not only syntactically motivated due to the occurrence of a jussive entity in the structure but also phonologically because there are certain specific environments in which such process take place.
\end{abstract}

Index Terms - vowels, consonants, deletion, reduction, lax, tense

\section{INTRODUCTION}

Deletion is a universal phonological process in which a vowel or consonant is dropped from an entity regardless of its class. The relevant literature shows that there were a number of Arab linguists who gave the issue a great significance. For instance, Maghalsih (2007) argued that jussive is a kind of mood restricted in its occurrence to the verb of the imperfective in a structure. The deletion of a vowel or/and consonant from the end of the jussive verb marks this structure; the same vowel is used as a finite tense marker in Arabic syntax in the indicative form before being dropped when preceded by a jussive particle. The indicative verb becomes jussive in three situations: (i) al-sukūn 'voweless consonant or quiescence', as in [la tadhhab- $\emptyset$ ila al-madrasati 'do not go to school']. The verb tadhhab carries the jussive marker zero as it is preceded by the negative item la 'not'. It carries the form yadhhabu 'goes' in the indicative before being used in mood. In other words, the short vowel [u] is the present tense marker. (ii) $h \square a d h f h \square a r f a l-{ }^{c} i l l i h$ min akkirihi 'elision of a short vowel from the end of the imperfective verb' as in [ wa-la tamshi- $\emptyset$ fi al-ard $\square i$ marah $\square$ an 'And walk not on the earth with conceit and arrogance'. In this case, the verb tamshi 'walk' is in jussive mood and is reduced vowel [i]. The verb carries the form of tamshi 'walks' in the indicative before being used in mood (c.f. Honorific Qur'an, p. 373, verse, 37). (iii) $h \square$ adhf al-nūn min ākhirihi 'the deletion of the alveolar nasal [n] from the end of the imperfective verb' as in ['aw lam yaraw- Ø 'anna nasūqu al-mā'a 'ila al-'ard $\square i$ al-jurzi 'have they not seen how We drive water to the dry land'] (c.f. Honorific Qur'an, p. 558, verse, 27). In this situation, the verb yaraw 'see' bears the zero markers since the nasal $[\mathrm{n}]$ and $[\mathrm{u}]$ are omitted. It is evident that the verb carries the form yarawna 'see' in which $/ \mathrm{n} /$ and /a/ are overt before being in jussive mood. The elision of the structure [na] normally occurs if any of $a l-\mathbf{l}^{c} a \bar{l}$ alkhamsih 'five verbs' is used. They follow the conjugation forms of (1) yaf́alüna 'they do', (2) taf alüna 'you pl do', (3) taf́alāna 'you both do', (4) yaf́calāna 'they both do' and (5) taf́calina 'you feminine singular do' (, p. 78).

In the international literature, Schane (1973) focused on deletion of segments and stated that a consonant is omitted in an environment due to feature changing. For instance, the word- final consonants, in French, are deleted when the following word begins with another consonant or a liquid as in [petit tableau 'a small picture'] which becomes [peti tablo] and [petit livre 'A small book' ] becomes [peti livre]. However, they are retained when the following word begins with a vowel as in [petit ami 'a small friend' remains [petit ami] and a glide as in [petit oiseau 'a small bird'] remains [petit waso]. Not only a consonant but also a vowel is omitted if the vowel of the definite article $l e$ or $l a$ 'the' is followed by another vowel in a word boundary as in [le ami 'the boy'] which becomes [1 ami] (c.f. p. 52-53). He also argued that certain English morphemes terminating in a vowel drop the vowel before a suffix beginning with a vowel as in [Mexico] which become [Mexican] which is derived from [Mexico + an] in which the vowel [o] is deleted. In another example, the vowel [o] is dropped if the suffix is initiated by a vowel as in [cello $+i s t]$ which becomes cellist (p. 53).

Fromkin (1983) confirmed that the velar voiced consonant $[\mathrm{g}]$ is deleted when it occurs before a final nasal consonant as in 'sign' [sãyn]. This is applied to a number of words in English such as resign, phlegm, diaphragm, paradigm, design...etc. Likewise, delete a word final $/ \mathrm{b} /$ when it occurs after an $/ \mathrm{m} / \mathrm{as}$ in 'bomb' /bamb/ but phonetically it is [bām]. This is applied to words such as iamb, crumb and bomb (p. 133). A vowel may also be reduced in certain environments due to phonetic and phonological or syntactic reasons; for instance, in English a vowel reduction involves the weakening of unstressed vowels to schwa. It displays morphological as well as syntactic alternations between a stressed full vowel and unstressed reduced schwa; for instance, the high long vowel [i] in 
compete [kompit] becomes [ə] if the verb is changed to a noun as competition [kompətI In]. Likewise, the high short vowel [o] in phone becomes [ə] if the other forms of a noun are given as in phonology [fənolod3I] (p. 91). As the reduced vowels are derived from different underlying phonemes, [ə] is an allophone of them. Thus, the process of vowel reduction in English is syntactically motivated in the sense that the schwa changes the class of the word from a verb to a noun as a specimen of the category. Not only reduced but also a vowel can be deleted in English. For instance, 'he is' [hi Iz] can be said as 'he's' [hiz] in casual speech. In ordinary everyday speech most of English native speakers delete the unstressed short vowels that are italicized bold in mystery, general, memory, funeral, personal, vigorous and Barbara ( p. 89).

Lass (1984) argued that if a segment can merge from zero, it can also be deleted. He illustrated three different types of deletions based on the position of the deleted segment. For instance, if the deletion happens in the initial position, it is aphaeresis as [I am] becomes [I'm] in which the vowel [a] is deleted because of contraction. If the deletion happens at the medial position, it is called syncope as in [sckrIterI] 'secretary' in American style of articulation or [sckrItrI] 'secretary' in British pronunciation of the same word in which [ $\varepsilon]$ is deleted. And finally, if the deletion of segment happens at the end of the word, it is called apocope. To take Swedish, in Sandhi the final vowel [a] of a nominal stem is deleted before the plural suffix [or] as in [flicka 'girl' becomes flickor 'girls' (p.186-187).

In the relevant literature, Wright (1984) and Abdulhamid (1995) mentioned that Arabic has two types of jussive particles. (i) The ones that have the ability to perform jussive on one verb and (ii) the ones that have the ability to perform jussive on two verbs ${ }^{(\mathbf{1})}$.

\section{PROBLem OF THE StUdy}

Deletion and /or reduction of a vowel and the nasal consonant /n/, in particular, take place in various ways in jussive verbs. Such phonological processes never happens to the same verb in the indicative form. These phenomena need to be checked in a concise manner with reference to Chomsky's and Halle's (1968) views of distinctive features and phonological rules. This work is an attempt to check the exact environments in which such segments succumb to change and find justifications for the change. To capture the nature of change, certain distinctive features and restricted phonological rules are posited to differentiate between segments.

\section{OBJECTIVES AND QUESTIONS OF THE STUDY}

The objectives of this research are to find correct solutions to the reasons behind deletion and/ or reduction of segments at the end of the verb in the jussive form that makes it entirely different from indicative. To solve the above issues, the following questions are being asked.

1. What is the exact segment that succumbed to deletion or any other phonological change?

2. What are the environments in which a vowel is deleted?

3. What are the environments in which the nasal components [na] are deleted?

4. What are the environments in which a vowel is reduced?

5. How do the distinctive features help the researcher posit correct phonological rules to differentiate between segments in various environments?

\section{TheOreticAl VieWs of GENERATIVE PhONOLOGY}

The researcher refers to Chomsky's and Halle's views on generative phonology to account for each segmental change and test the environments in which the change took place and differentiate between them by using the distinctive features of the generative phonological theory at the underlying as well as the surface levels; thus certain phonological rules are to be posited to govern the change and specify each environment. Chomsky and Halle (1968) posited specific distinctive features to distinguish vowels from consonants on one hand and vowels from each other on the other whenever a vowel is deleted and/or reduced. They involve (i) features of the major class, (ii) body of tongue and (iii) sonorant/ non-sonorant (obstruent) (iv) syllabic/ non-syllabic. Such features are discussed in detail as follows:

\section{A. Major Class Features}

The distinction between vowels and consonants is not only related to articulatory mechanism but also to voicing. Thus, the production of vowels did not involve any major contact between articulators as compared to consonants. In such situations, the airstreams are not obstructed at any point in the vocal tract; however, in the production of consonants, a major constriction at some point along the vocal tract was always there. As known, all vowels in English are voiced; whereas, in case of consonants some of them are [+voiced] and others are [-voiced]. To account for other differences between segments, let us look to the analysis below:

1. Vocalic - non-vocalic

These two features are used to describe sounds produced with an oral cavity in which the most radical constriction does not exceed that found in the high vowels [i] and [u] and with vocal cords that are positioned so as to allow spontaneous voicing as vocalic; however, non- vocalic sounds one or both of these conditions are not met.

2. Consonantal - non-consonantal 
These two features are used to distinguish between vowels and consonants as two primary classes. Consonantal sounds are produced with a radical obstruction in the midsagittal region of the vocal tract; while, non- consonantal sounds are produced without such an obstruction. The former includes liquids; nasal and non- nasal consonants while the latter includes voiced vowels, voiceless vowels, glides [w, j] and [h, ?].

3. Sonorant-non-sonorant (obstruent)

These two features are introduced to distinguish sounds that allow spontaneous voicing from sounds that do not respectively. The sonorant segments are vowels, glides, liquids and nasals while the non-sonorant are fricatives and affricates. A refinement of these features is described as syllabic and vocoid (vowel-like in nature); hence, glides are characterized as non-syllabic and vocoid. Thus, the articulatory similarity between vowels and glides is captured by the distribution in the position of syllable nuclei. Consonants are described as contoids and vowels as vocoids while the same distinction

4. syllabic/non-syllabic

They are used basically to differentiated between vowels and glides; however, it operates in the case of consonants. Vowels are syllabic but glides are not; furthermore, nasals and liquids are syllabic but obstruent consonants are nonsyllabic ones. It must be mentioned that [ \pm syllabic] is a different type of feature since it refers to the possibility of occurrence (distribution) of a sound in a given position (context) - i.e. syllable nucleus.

\section{B. Cavity Features}

There are certain features to distinguish consonants from each other.

1. Coronal / non-coronal: the former is used to describe sounds produced with the blade of the tongue raised from the neutral position. It includes dental, alveolar, palato-alveolar consonants; however, non-coronal is used to describe the sounds articulated with lips or with the body of the tongue in the neutral position. It includes glides, vowels, uvula and non retroflex vowels.

2. Anterior / non-anterior: the former is used to describe sounds that are produced with an obstruction that is located in front of the palato-alveolar region of the mouth; it includes labials, dentals and alveolars; but, non- anterior sound are produced without such an obstruction. It has palato-alveolar, retroflex, palatal, velar, uvular and pharyngeal.

\section{Body of Tongue Features}

There are certain distinctive features relating to the tongue body to define vowels; they include:

1. High-non- high

High sounds are produced by raising the body of the tongue above the level that occupies in the neutral position. It includes [i and $\mathrm{u}$ ]. Non- high sounds are produced without such rising the body of the tongue; it involves the vowels [e, $\epsilon$, a, a, o and $\square]$.

2. Low- non- Low

Low sounds are produced by lowering the body of the tongue below the level that it occupies in the neutral position; it contains [a and $\alpha$ ]. However, non- low sound are produced without such lowering the body of the tongue. It has [i, $u$, $\mathrm{e}, \epsilon, \mathrm{o}$ and $\square]$.

3. Back-non back

Back- non back: back sounds are produced by retracting the body of the tongue form the neutral position; it consists of $[a, \square, o$ and $\mathrm{u}]$. Non - back sounds are produced without such retraction from the neutral position; it has [i, e, $\epsilon$, and a]. (c.f. 1968:305).

\section{Rounded/un-rounded}

The feature rounded/un-rounded makes a distinction between vowels pronounced with either rounded as in [u, o, and $\mathrm{a}$ ] and spread lips as in [ I, e, $\mathrm{\epsilon}$ and a].

The above relevant features will be used to check the environment in which a consonant and vowel is deleted or reduced in Arabic phonology of jussive verbs, in particular.

\section{Deletion of A Vowel in Jussive Verb}

Deletion is a phonological process in which a segment is omitted either initially, medially or finally. The deleted segment bears certain distinctive generative features and is represented by the symbol $[\varnothing]$ in the structure and for which a phonological rule is posited. As far as the jussive structure level, in Arabic, is concerned, a segment is to be deleted from the end of a verb if it is in the jussive form or else the structure is ungrammatical at the syntactic as well as phonetic level. Syntactically, Arabic has a number of jussive entities of different natures; if any one of them precedes the verb of imperfective, certain phonetic articulatory change of segments has to happen. The entities are represented by: (i) lam ' not', (ii) lamma ' not', (iii) li 'let', (iv) la 'not', (vii) 'in 'if', (viii) man 'who', (ix) ma 'whatever', (x) mahma 'whatever', (xi) 'aiyana 'when', (xii), $h \square$ aithuma 'whenever', (xiii) kaifama ' however', (xiv) 'aina 'where' and (xv) 'nna ' wherever'. As the effect maximally occurs to vowels, the researcher is enforced to mention the quality of them in Arabic. There are the high front tense vowel [i] , the high front lax vowel [i], the high back tense vowel [ū], the high back lax vowel $[\mathrm{u}]$, the law front tense vowel $[\bar{a}]$ and the low front lax vowel [a]. Arabic, like any other languages in the world, accepts the deletion of a vowel in a final position; to account for this issue, the researcher provides the instances in (1). 
Indicative Sentence

$\begin{array}{lllll}\text { 1a. ya } & \text { drus } & -\boldsymbol{u} & { }^{\mathrm{c}} \text { aliyyun/ } & \text { wah } \square \overline{1} \text { dun } \\ 3^{\text {rd }}, \text { sg,masc. } & \text { study } & \text { pres. } & \text { Ali } & \text { Wahid }\end{array}$

'Ali/ or Wahid studies'

Jussive Sentnce

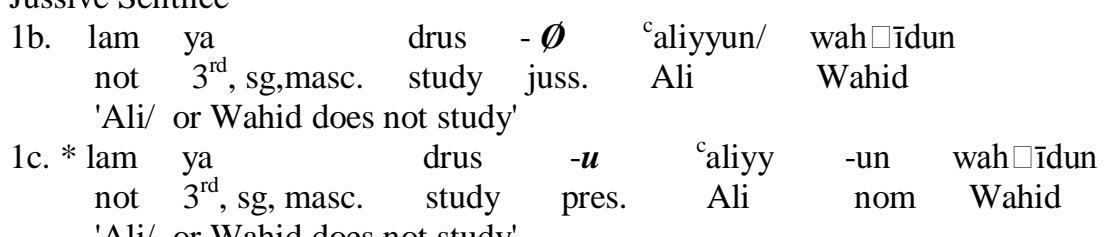

(1a) illustrates that the verb yadrus- $u$ 'he studies' is in the indicative form; thus, it carries the present marker [u] attached to it. However, if the verb is made jussive mood by adding the negative entity lam 'not' to the initial position of the sentence, the vowel $[\mathrm{u}]$ must be dropped as in $(1 \mathrm{~b})$ or else the sentence is ungrammatical as in (1c). The deletion, of $[\mathrm{u}]$ in (1b), is captured by the phonological rule (1d).

$\left[\begin{array}{l}\text { ld. } \\ + \text { vocalic } \\ + \text { back } \\ + \text { round } \\ \text {-low }\end{array}\right] \longrightarrow \varnothing /-\left[\begin{array}{c}\{\mathrm{C} \& \text { - vocalic }\} \\ \text {-consonantal } \\ \end{array}\right]$

The rule (1d) reads as that the vowel [u] must be deleted if is followed by a consonant $(\mathrm{C})$ or a semi- vowel. It is evident that if this rule is applied to (1a), it will not be applied because there is no phonological process is evolved.

If a verb of jussive carries the plural form in a verbal sentence, Arabic accepts the deletion of the same vowel $[u]$, the nasal consonant $[n]$ and its conjoint i.e. the vowel [a] (i.e. the plural marker). This phenomenon happens if the verb in which the structure [una] preceded by any jussive item. The example (2) is a specimen of the environment.

Indicative Sentence

$$
\begin{aligned}
& \text { 2a ya- sm } u \text { u una r- rijālu } \\
& 3^{\text {rd }} \text {, pl,masc. gohigh pres. pl. det men }
\end{aligned}
$$

'The men enjoy high positions'

\begin{tabular}{|c|c|c|c|c|c|c|c|}
\hline $\begin{array}{l}\text { 2b. li } \\
\text { let }\end{array}$ & $\begin{array}{l}\text { ya- } \\
3^{\text {rd }}, \text { pl,masc. }\end{array}$ & $\begin{array}{l}\text { sm } \\
\text { go high }\end{array}$ & $\begin{array}{l}-0 \\
\text { juss. }\end{array}$ & $\begin{array}{l}\boldsymbol{u} \\
\mathrm{pl}\end{array}$ & $\varnothing$ & $\begin{array}{l}\mathrm{r}- \\
\mathrm{det}\end{array}$ & $\begin{array}{l}\text { rijālu } \\
\text { men }\end{array}$ \\
\hline \multicolumn{8}{|c|}{ 'Let the men enjoy high positions' } \\
\hline 2c. $*$ li & $\underset{3^{\text {rd }}, \text { pl,masc. }}{\text { ya- }}$ & $\begin{array}{l}\text { sm } \\
\text { go high }\end{array}$ & $\begin{array}{l}-0 \\
\text { juss. }\end{array}$ & $\begin{array}{l}\boldsymbol{u} \\
\mathrm{pl}\end{array}$ & na & $\begin{array}{l}\mathrm{r}- \\
\mathrm{det}\end{array}$ & $\begin{array}{l}\text { rijālu } \\
\text { men }\end{array}$ \\
\hline
\end{tabular}

Jussive Sentence

'Let the men enjoy high positions'

(2a) illustrates the actual overt markers of tense [u] and plural [una] of the indicative form of the verb yamsu 'enjoy high position'. (2b) illustrates that the tense marker $[u]$ deleted due to the overt pre-occurrence of the jussive permissive entity $l i$ 'let'. However, the remnant parts of the plural marker i.e. [na] are to be deleted as they are followed by the assimilated liquid $[\mathrm{r}]$ as a specimen of a number of a assimilated segments such $\left[1, \mathrm{r}, \mathrm{n}, \int, \theta, \mathrm{\partial}, \mathrm{s}, \mathrm{s} \square, \mathrm{z}, \mathrm{\partial} \square, \mathrm{d}, \mathrm{d} \square, \mathrm{t} \square, \mathrm{t}\right]$ that have the features [+coronal, +anterior]. These phonological phenomena in $(2 \mathrm{~b})$ are captured by the phonological rules $(2 \mathrm{~d})$ and $(2 \mathrm{e})$ respectively.

$$
\left[\begin{array}{l}
\text { [+ vocalic }] \\
+ \text { lax } \\
\text { +back } \\
\text { +round } \\
\text {-low }
\end{array}\right] \longrightarrow \varnothing / \quad-\left[\begin{array}{ll}
+ \text { vocalic \& + nasal } \\
+ \text { lax } & \text { + coronal } \\
+ \text { back } & \text { +anterior } \\
+ \text { round } & \\
\text { - low }
\end{array}\right]
$$

$(2 \mathrm{~d})$ is read as that the vowel $[\mathrm{u}]$ is deleted if it is followed by $[\mathrm{u}]$ and the nasal $[\mathrm{n}]$.

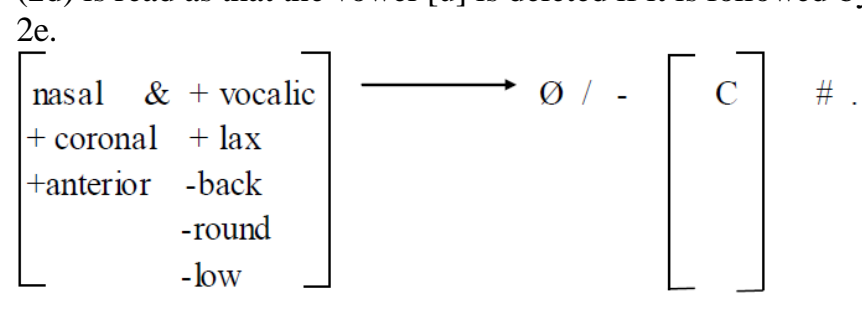


(2e) is read as that the components [na] are omitted if they are followed by a consonant in boundary. These two phonological rules of $(2 \mathrm{~d})$ and (2e) cannot be conjoined as they talk about a vowel and the nasal [n].

Likewise, in (3a), Arabic accepts the short vowel $[a]$ and the parts of the plural markers [na] to be deleted from the verb $y a s^{c} a$ 'seek' when the verb bears the plural form and is used in jussive form as in (3).

Indicative Sentence

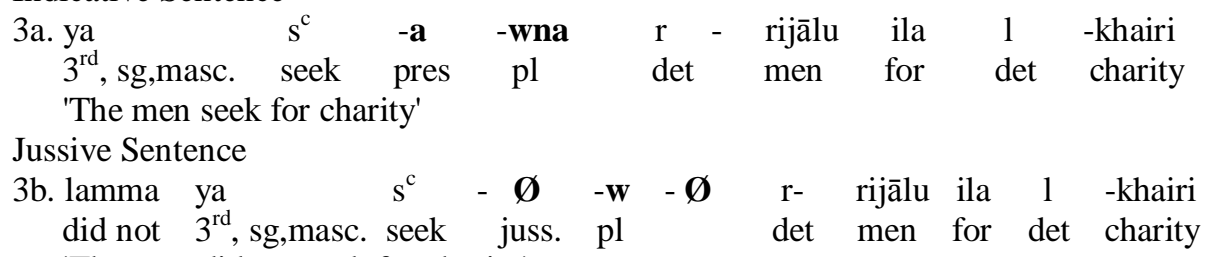

'The men did not seek for charity'

(3a) is an indicative sentence in which the present tense is visible with the marker [a] to which the plural marker [wna] is also added. Once the negative jussive polarity item lamma 'not' occurs before the verb, the vowel [a] of the present tense and the second part of the plural marker [na] are to be deleted as in (3b). Such phonological changes are shown in the phonological rules (3c) and (3d) respectively. It is evident that jussive cannot have visible tense though it is a finite structure which is similar to subjunctive structures in Arabic syntax.

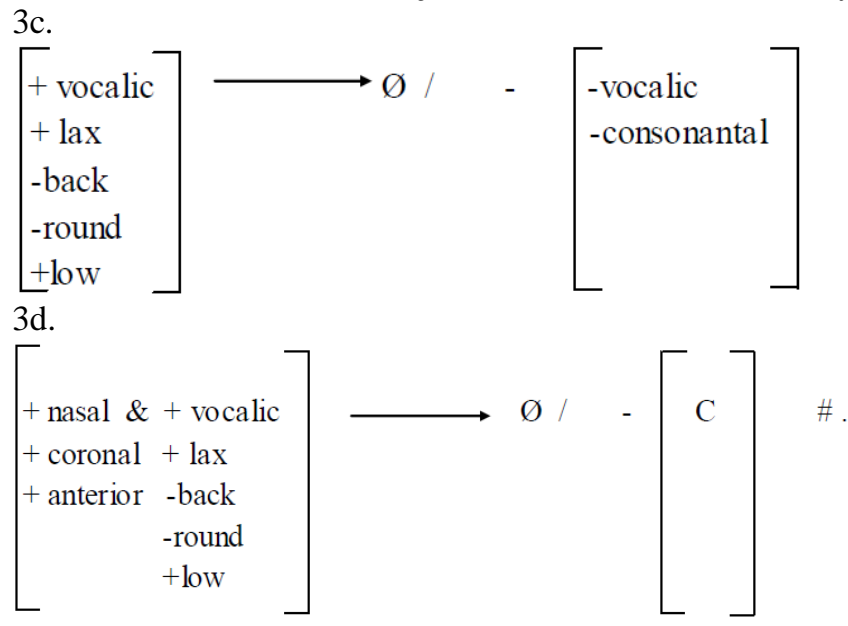

(3c) and (3d) cannot be conjoined as one rule as they have different segments. In other words, there is the nasal [n] that has different distinctive features which are irrelevant to vowels. In short, it is obvious that the deletion of the segments [u], [a], [n] and [w] are not only syntactically motivated but also phonologically manifested; this is due to the fact that the structure is changed to jussive which is entirely different from indicative in two features: (i) the overt occurrence of a jussive entity, (ii) the deletion of the tense marker and the second part of the plural markers [na] without changing the finiteness of the structure. There are some other verbs of the category that are treated in the same manner once they are preceded by any jussive entity; they are listed in (4).

4. i. yas ${ }^{\mathrm{c} a} \quad$ 'to seek good act'

ii. yarqa 'to go high'

iii. yan'a 'to go aside

iv. $\operatorname{yaqn}^{\mathrm{c}} \mathrm{a} \quad$ 'to condole'

v. yabqa 'to stay'

vi. $\mathrm{yn}^{\mathrm{c}} \mathrm{a} \quad$ 'to condole'

In short, once a jussive entity precedes the verb in the imperfective form, the short vowels $[\mathrm{u}]$, [a] and the plural conjoins [na] must be omitted for syntactic as well as phonetic reasons.

\section{Reduction of A Vowel in Jussive VerbS}

The only weak vowel in English is the schwa /ə / which is known as the reduced vowel. The schwa occurs as a result of a common phonetic process called vowel reduction, a process reduces a strong vowel into the schwa, the weak vowel when the syllable containing that vowel becomes unstressed. However, this phenomenon in Arabic is entirely different in the sense that the reduced vowel is not a schwa but a lax form of the same vowel and it is not weak. The researcher may give the specimens of (5) and (6) to illustrate the reduction of [ā] to [a] when two jussive entities occur.

Indicative Sentence

$\begin{array}{llllll}\text { 5a. ta- } & \text { lq } & \overline{\boldsymbol{a}} & \mathrm{d} \square \text { aifa- } & \text { ka } & \text { mustabshiran } \\ 2^{\text {nd }} \text {,sg,masc. } & \text { meet } & \text { pres. } & \text { guest } & \text { your } & \text { happy }\end{array}$

'You meet your guest if you are happy'

Jussive Sentence 
5b. *la ta- $\quad$ lq $\quad-\bar{a} \quad \mathrm{~d} \square$ aifa- $\quad$ ka illa mustabshiran

not $2^{\text {nd }}$, sg,masc meet juss. guest your unless happy

'Do not meet your guest unless you are happy'

5c. la ta- lq $-\boldsymbol{a}$ daifa- ka illa mustabshiran

not $2^{\text {nd }}$, sg,masc meet juss. guest your unless you are happy

'Do not meet your guest unless you are happy'

Indicative Sentence

$\begin{array}{llcccc}\text { 6a. ya- } & \operatorname{rd} \square & -\bar{a} & \text { bi } & \text { nas } \square \text { ìbi } & \text { hi } \\ 3^{\text {rd }}, \text { sg,masc. } & \text { accept } & \text { pres. } & \text { with } & \text { luck } & \text { his }\end{array}$

'He accepts his luck'

Jussive Sentence

\begin{tabular}{|c|c|c|c|c|c|}
\hline $\begin{array}{c}\text { 6b. *lam } \\
\text { not }\end{array}$ & $\begin{array}{l}\text { ya- } \\
3^{\text {rd }}, \text { sg,masc. }\end{array}$ & $\begin{array}{l}\mathrm{rd} \square \\
\text { accept }\end{array}$ & $\begin{array}{l}-\overline{\boldsymbol{a}} \\
\text { juss. }\end{array}$ & $\begin{array}{l}\text { bi } \\
\text { with }\end{array}$ & $\begin{array}{c}\text { nas } \square \text { ibi } \\
\text { luck }\end{array}$ \\
\hline 'I dic & $t$ accept my lu & & & & \\
\hline $\begin{array}{l}\text { lam } \\
\text { not }\end{array}$ & $\begin{array}{l}\text { ya- } \\
3^{\text {rd }} \text {, sg,masc. }\end{array}$ & $\begin{array}{l}\mathrm{rd} \square \\
\text { accept }\end{array}$ & $\begin{array}{l}-\boldsymbol{a} \\
\text { juss. }\end{array}$ & $\begin{array}{l}\text { bi } \\
\text { with }\end{array}$ & $\begin{array}{c}\text { nas } \square \overline{i b i} \\
\text { luck }\end{array}$ \\
\hline
\end{tabular}

'I did not accept my luck'

A look at (5a) and (6a) indicates that they are correct Arabic sentences because the tense vowel [ā] marks the imperfect verbs talqā 'meet' and yard $\square \bar{a}$ 'accepts'. As the same vowel is not reduced to lax in the presence of the jussive polarity negative entities $l a$ and lam 'not', (5b) and (6b) are incorrect. (5c) and (6c) are made correct since the vowel [ā] is reduced to the lax [a] in a word boundary. This phenomenon is captured in the phonological rule (7).

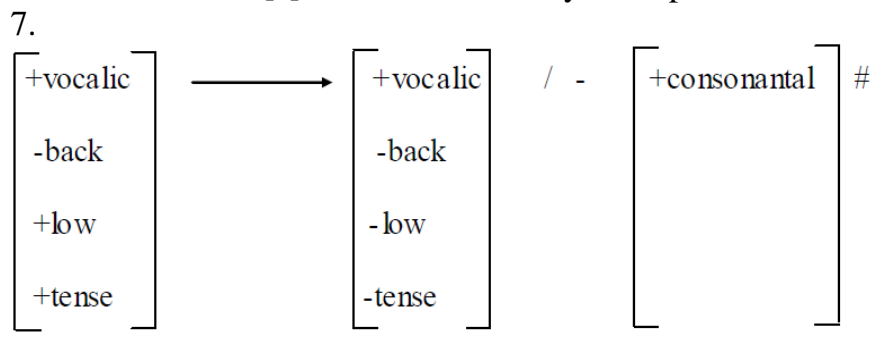

However, the same tense vowel $\overline{\bar{a}}]$ is reduced to lax [a] if it is followed by the definite article $a l$ 'the' and preceded by a jussive item. The sentences (8) and (9) illustrate the point of discussion with the occurrence of two other different jussive entities.

Indicative Sentence

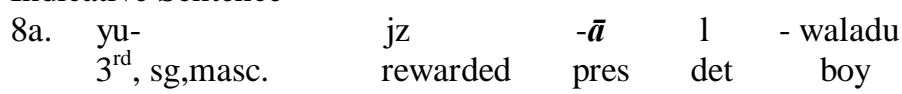

'The boy was rewarded'

Jussive Sentence

\begin{tabular}{|c|c|c|c|c|c|c|}
\hline $8 b$. & $\begin{array}{l}\text { * lamma } \\
\text { not }\end{array}$ & $\begin{array}{l}\text { yu- } \\
3^{\mathrm{rd}}, \mathrm{sg}, \text { masc. }\end{array}$ & $\begin{array}{l}\mathrm{jz} \\
\text { rewarded }\end{array}$ & $\begin{array}{c}-\overline{\boldsymbol{a}} \\
\text { juss. }\end{array}$ & $\begin{array}{c}1 \\
\text { det }\end{array}$ & $\begin{array}{l}\text { - waladu } \\
\text { boy }\end{array}$ \\
\hline & 'The boy & was not rewar & & & & \\
\hline 8c. & $\begin{array}{l}\text { lamma } \\
\text { not }\end{array}$ & $\begin{array}{l}\text { yu- } \\
3^{\mathrm{rd}}, \mathrm{sg}, \mathrm{masc} .\end{array}$ & $\begin{array}{l}\mathrm{jz} \\
\text { rewarded }\end{array}$ & $\begin{array}{l}-\boldsymbol{a} \\
\text { juss. }\end{array}$ & $\begin{array}{l}1 \\
\operatorname{det}\end{array}$ & $\begin{array}{c}\text { - waladu } \\
\text { boy }\end{array}$ \\
\hline
\end{tabular}

Indicative Sentence

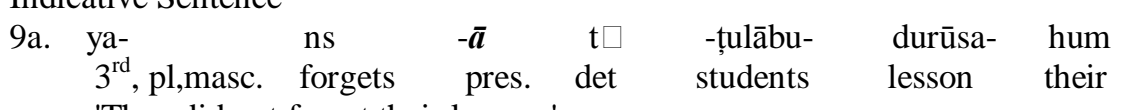

'They did not forget their lessons'

Jussive Sentence

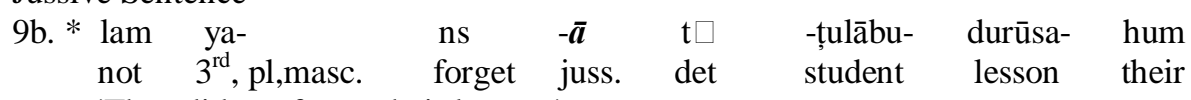

'They did not forget their lessons'

9c. lam ya- $\quad$ ns $\quad-a \quad t \square$-țulābu- durūsa- hum not $3^{\text {rd }}$, pl,masc. forget juss. det student lesson their

'They did not forget their lessons'

(8a) and (9a) are grammatical sentences because the imperfective tense marker represented by the tense vowel [ā] is not reduced. (8b) and (9b) are ungrammatical sentences because the same vowel remains tense in the occurrence of the jussive entities lamma and lam "not. These two sentences are made correct as in (8c) and (9c) because the vowel is reduced to [a]. the rule (10) covers the change.

10 . 


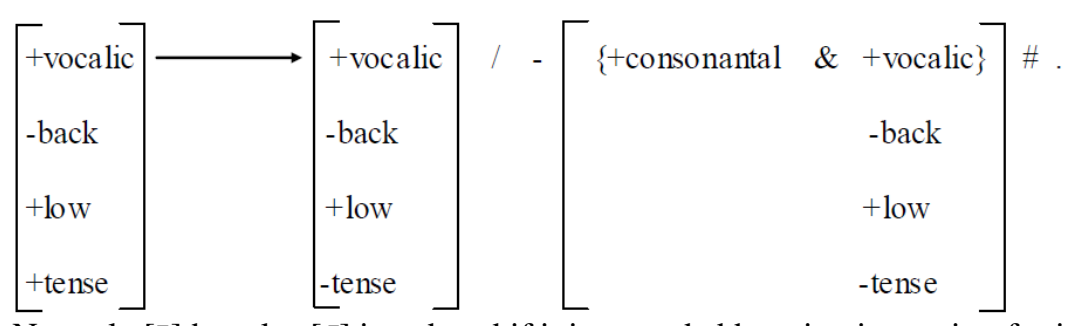

Not only $[\bar{a}]$ but also $[\bar{u}]$ is reduced if it is preceded by a jussive entity; for instance, man 'whoever' in $(11 \mathrm{~b}$ and c) and the conditional particle in 'if' in (12b and c) which are used respectively.

Indicative Sentence

11a. ya- $\quad$ sm $\quad-\overline{\boldsymbol{u}}$ bi akhlāgi hi

$3^{\text {rd }}$, sg,masc. go high pres with ethics his

'He enjoys high ethics'

Jussive Sentence

11b. * man ya- sm $-\overline{\boldsymbol{u}}$ bi akhlāgi hi ya- njah $\square$ u.

Whoever $3^{\text {rd }}$, sg,masc. went high juss. with ethics his he pass

'Whoever enjoys high ethics, he succeeds'

11c. man ya sm $-\boldsymbol{u}$ bi akhlāgi hi ya -njahu.

whoever $3^{\text {rd }}$, sg,mas. go high juss. with ethics his he pass

'Whoever enjoys high ethics, he succeeds'

Indicative Sentence

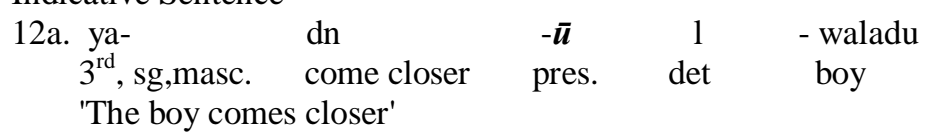

Jussive Sentence

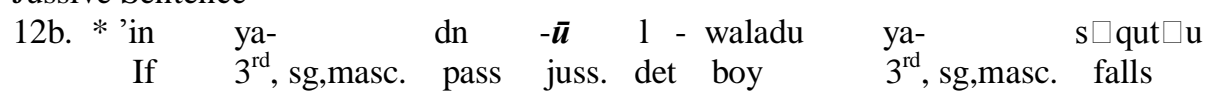

'If the boy comes closer, he falls'

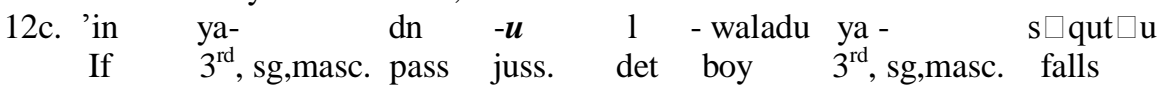

'If the boy comes closer, he falls'

(11a) and (12a) are normal indicative sentences in which the imperfective verbs are marked by the tense marker [ū]. However, (11b) and (12b) are incorrect because the jussive entities, namely, man 'whoever' and 'in 'if' are overt and the tense vowel $[\overline{\mathrm{u}}]$ is not reduced to lax. As, the same vowel is reduced in (11c) and (12c) in the verbs yasmu 'go high' and yadnu 'comes closer' respectively, the sentences are made correct. It is evident also that, in $(12 \mathrm{c})$, as the vowel [u] is followed by the definite $a l$ 'the', [a] is deleted. In short, if the high back tense rounded vowel [ $\bar{u}]$ is preceded by a jussive entity and followed by a consonant, it is reduced to lax; however, if it is followed by the unique the definite article $a l$, it is reduced ; moreover, [a] of the article is omitted. The reduction process of the tense [ū] is shown in the phonological rule (13)

13.

$\left[\begin{array}{l}\text { +vocalic } \\ + \text { back } \\ \text {-low } \\ + \text { tense }\end{array}\right]\left[\begin{array}{l}\text { +vocalic } \\ \text {-back } \\ \text {-low } \\ \text {-tense }\end{array}\right],-\left[\begin{array}{c}\text { +consonantal \& + vocalic }\} \\ \text {-back } \\ + \text { low } \\ \text {-tense }\end{array}\right]$ \#

The rule (13) indicates that the vowel $[\overline{\mathrm{u}}]$ is reduced to $[\mathrm{u}]$ whenever followed either by a consonant or the lax vowel [a] of the article al.

Likewise, the high front tense vowel [i] is reduced to lax whenever the jussive verb is preceded by any jussive entity such as the specific adverbial entity mata 'when' in (14c) and the polarity negative item lam 'not' in (15c) respectively.

Indicative Sentence

$14 \mathrm{a}$ ya- 't $\quad-\overline{\boldsymbol{i}}$ faşlu al $\quad$ shitā' $3^{\text {rd }}$, sg,masc. come pres. season det winter

'Winter comes'

Jussive Sentence

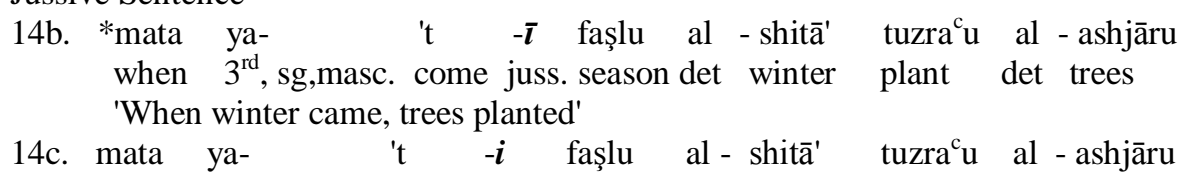


when $3^{\text {rd }}$, sg,masc. come juss. season det winter planted det trees

'When winter came, trees planted'

Indicative Sentence

15a. ya- rm $-\overline{\boldsymbol{t}}$ r- rajulu shawkan fi al -țarīqi

$3^{\text {rd }}$, sg,masc. throw pres det man thorns on det road

'He throws thorns on the road'

Jussive Sentence

15b. *lam ya- rm $-\overline{\boldsymbol{\imath}}$ r- rajulu shawkan fi al -țarīqi

not $3^{\text {rd }}$, sg,masc. throw juss. det man thorns on det road

'He did not throw thorns on the road'

15c. lam ya- rm $-i \quad r-$ rajulu shawkan fi al -țarīqi

not $3^{\text {rd }}$, sg,masc. throw juss. det man thorns on det road

'He did not throw thorns on the road'

(14a) and (15a) are grammatical indicative sentences in which the verbs ya'tī 'come' and yarmī 'throw' are marked by the tense vowel[1] . (14b) and (15b) read wrong as the same vowel retain the same quality. In (13c) and (14c), [i] is reduced to lax and the vowel [a] of the article $a l$ is deleted and [1] is assimilated to [r]. the reduction of the vowel is seen in (16).

$\left[\begin{array}{l}16 . \\ \text {-bocalic } \\ \text {-low } \\ \text { +tense }\end{array}\right] \longrightarrow\left[\begin{array}{l}\text { +vocalic } \\ \text {-back } \\ \text {-low } \\ \text {-tense }\end{array}\right] /-\left[\begin{array}{ll}\{+ \text { consonantal } & \& \text { +vocalic }\} \\ \text {-back } \\ + \text { low } \\ + \text { lax }\end{array}\right]$ \#

To sum up, the tense vowels $[\bar{a}],[\bar{u}]$ and $[\overline{1}]$ at the end of the imperfective verbs of jussive are reduced to lax if the verbs in which they occur are preceded by the given jussive entities and followed either by a consonant or particularly the lax vowel [a] of the definite article al 'the' as shown in the phonological rule (16); thus, the rules (7), (10), (13) and (16) are joined in one phonological rule as in (17).

17.

$\left[\begin{array}{c}+ \text { vocalic } \\ + \text { tense }\end{array}\right] \longrightarrow\left[\begin{array}{c}\text { vocalic } \\ - \text { tense } \\ \end{array}\right] /-\left[\begin{array}{c}\text { +consonantal \& }+ \text { vocalic }\} \\ \text {-tense } \\ + \text { low } \\ \text {-back }\end{array}\right]$ \#

We may notice that the vowel reduction process is not only syntactically but also phonetically motivated because Arabic has this unique syntactic phenomenon among languages.

To sum up;

This study has come out with new results as compared to previous studies. This fact is based on the fake results that have been achieved by the Arab phoneticians. They are constantly claiming that jussive is marked either by (1) the zero marker, (2) deletion of a vowel and (3) deletion of the nasal [n] from the end of the jussive verb. Such drawbacks took place due to the following reasons. They based their analysis merely on the surface structure representations rather than going to deeper levels; second they did not specify the real qualities of the deleted vowel. Third, they did not realize that the plural marker is composed of [n] and the vowel [a] but not merely [n]. As contrasted to the current study, the results are summarized as follows: (i) jussive is actually marked by the deletion of the lax vowels of [a] and [u] but not [i] at the underlying level and continued to be covert at the surface level; this contradicts point (1). (ii) The vowels [āa $\bar{u} \& \overline{1}]$ are reduced to become lax at the underlying level and are retained to the surface level. This point also contradicts the point (2) a head. (iii) The nasal components [na] but not merely [n] are deleted at the same underlying level as contrasted to point (3). These new results are confirmed by the posited phonological rules which cannot be applied at the surface level otherwise.

\section{CONCLUSION}

It is obvious that the segments that succumb to deletion and reduction occur merely at the end of the imperfective jussive verb at the underlying level but not of the imperfective indicative. The deleted segments are the high back round lax vowel [u] and the high front lax vowel [a]; however, the vowel [i] is not deleted. Moreover, the nasal components [na] are also deleted in the same process. It is obvious that there are different environments in which a vowel is deleted; for instance, the lax vowel $[\mathrm{u}]$ is deleted if the verb to which it is attached is preceded by the jussive specimen lam 'not and followed by a consonant as in (1) and by the vowel [u] of the plural marker [una] as in (2). Not only [u] but also [a] 
is deleted if the verb to which it is attached is preceded by the jussive specimen lamma 'did not' and followed by the semi-vowel [w] of the plural marker [wna] as in (3). This [w] is retained while the components [na] are to be deleted if followed by the assimilated liquid [r]. Similar assimilated segments that are treated like [r] include [1, r, n, $\int, \theta, ð, s, s \square$, $\mathrm{z}, \mathrm{\partial} \square, \mathrm{d}, \mathrm{d} \square, \mathrm{t} \square, \& \mathrm{t}]$. The vowel [ā] is reduced if followed by a consonant as in (5c); it is also reduced if followed by the lax vowel [a] of the definite article $a l$ 'the' as in $(6 \mathrm{c}, 8 \mathrm{c} \& 9 \mathrm{c})$ in a word boundary. It is evident that the liquid [1], in (8c), is not assimilated to [w]; however, the same segment is totally assimilated to [t $\square$ ] in a regressive manner in (9c). The vowel $[\overline{\mathrm{u}}]$ is reduced to lax if followed by a consonant as in (11c). Moreover, it is reduced if it is followed by the lax vowel [a] of the same article as in (12c). Finally the vowel [i] reduced to lax if followed by a consonant as in (14c) and if followed by the lax vowel [a] of the same definite article as in (15c). There is also a total assimilation of the liquid [1] to [r] in a regressive style in the same sentence. The distinctive features proposed by Chomsky and Halle (1968) are of a great help to formulate new phonological rules that differentiate between segments that are deleted and reduced and govern their environments in a prices manner.

\section{TRAnSLiteration Symbols of ARABiC CONSONANTs PhONEMES}

\begin{tabular}{|c|c|c|c|}
\hline Arabic & Transliteration & Arabic & Transliteration \\
\hline أ & ' & ض & d \\
\hline ب & $\mathrm{b}$ & b & $t$ \\
\hline$ت$ & $t$ & ظ & $z_{1}$ \\
\hline$\Xi$ & th & $\varepsilon$ & c \\
\hline ج & $\mathrm{j}$ & $\dot{\varepsilon}$ & $\mathrm{gh}$ \\
\hline$\tau$ & $\mathrm{h}_{\mathrm{r}}$ & ف & $\mathrm{f}$ \\
\hline$\dot{\tau}$ & $\mathrm{kh}$ & ق & $\mathrm{q}$ \\
\hline د & $\mathrm{d}$ & 5 & $\mathrm{k}$ \\
\hline$\dot{j}$ & $\mathrm{dh}$ & J & 1 \\
\hline J & $\mathrm{r}$ & 5 & $\mathrm{~m}$ \\
\hline j & $\mathrm{z}$ & ن & $\mathrm{n}$ \\
\hline س س & $\mathrm{sh}$ & 9 & $\mathrm{w}$ \\
\hline ص ص & S & ي & $\mathrm{y}$ \\
\hline
\end{tabular}

Notice: the researcher has a reference to the transliteration symbols while writing the Arabic phonemic segments in the text. (c.f. Oxford Journal for Islamic Studies)

IX. Transliteration Symbols of Arabic Vowels Phonemes

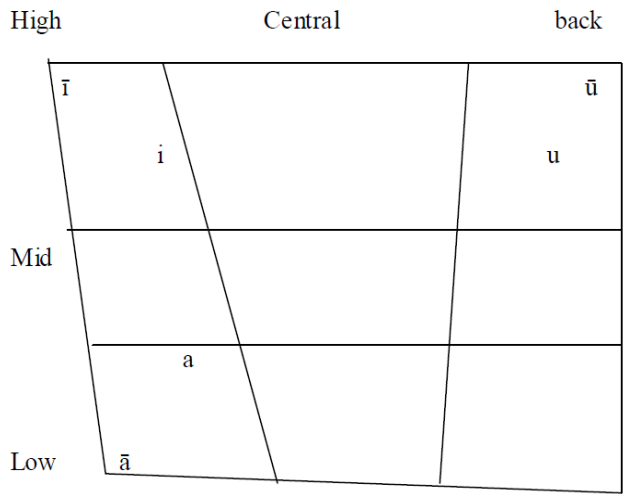

(c.f. Oxford Journal for Islamic Studies)

\section{Standard Arabic Phonetic Symbols of Consonants AS PER IPA}




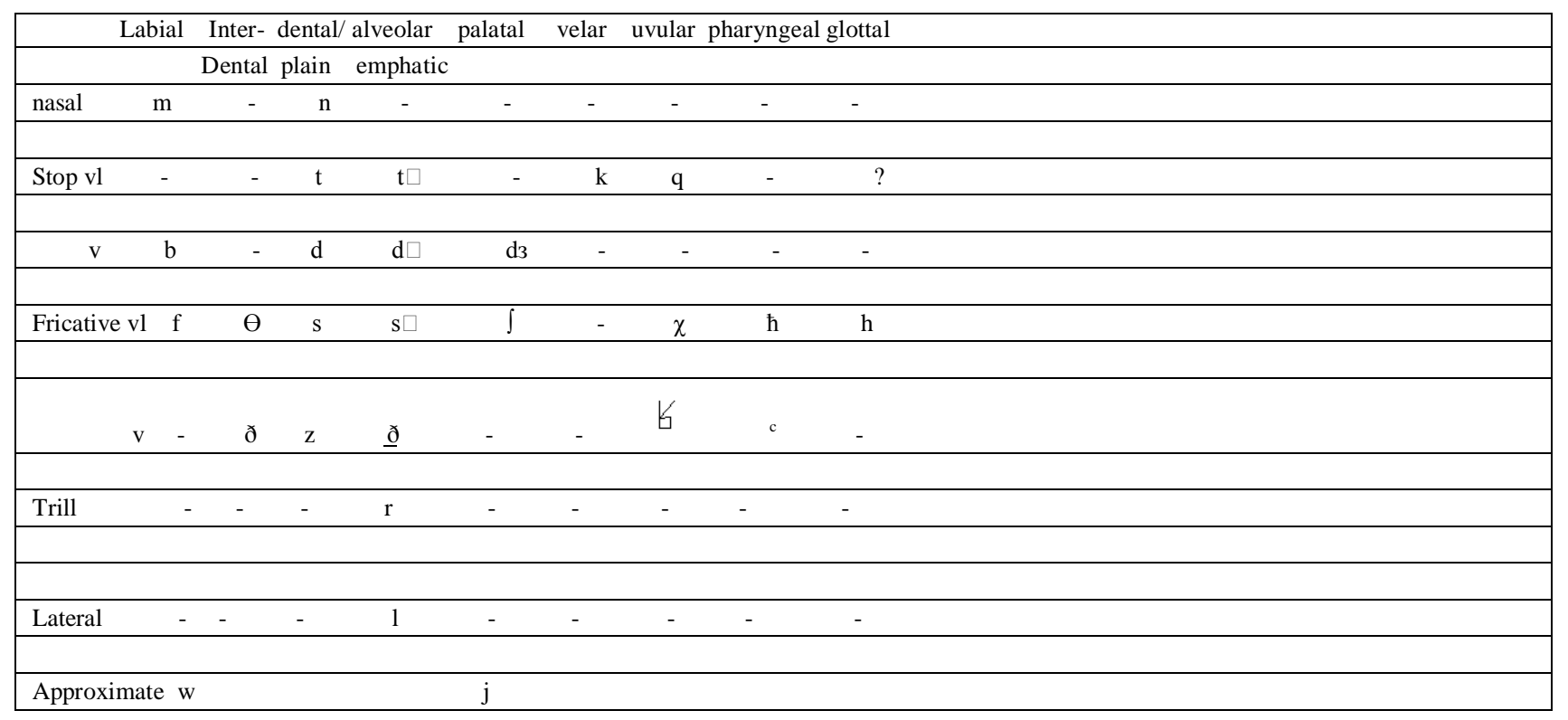

Notice: the researchers do not refer to the phonetic symbols but they used merely the transliteration ones while writing the Arabic specimens in the text. The phonetic symbols are listed only for knowledge (c.f, http:/en wikipedia.org/wiki Arabic Phonology).

\section{REFERENCES}

[1] Abdulhamid, M. (1995). Sharh ibn ${ }^{c}$ aqiil. Beirut: Al- Maktabah Al- ${ }^{c}$ aşriyeh.

[2] Chomsky, N. and Halle, M. (1968). The sound pattern of English. Cambridge: MIT Press.

[3] Fromkin, V., and Rodman, R. (1983). An introduction to language. Japan: College Publishing.

[4] Lass, R. (1984). Phonology: An introduction to basic concepts. Cambridge: U.K

[5] Maghalsih, M. (2007). Al-nahu al-shafi al- shamil. Amman: Dar Al- Masirah.

[6] Noble Qur'an. (1417). English translation of the meanings and commentary. Kingdome of Saudi Arabia: Madinah Munawwara.

[7] Schane, S. (1973). Generative phonology. Prentice- Hall. Englewood Cliffs, N.J.

[8] Wright, W. (1984). Grammar of the Arabic language. New Delhi: S. Chand and Company.

Atef Mustafa Jalabneh was born in Ajloun -Ibbin on Eigh $^{\text {th }}$-July -1960. He got his MA, M. Phil and PhD degrees in linguistics from Department of Linguistics/ Delhi University/ India by 1996.

$\mathrm{He}$ is currently occupying an ASSOCIATE PROFESSOR position in Department of English/ Faculty of Languages and Translation/ King Khalid University / Saudi Arabia/ Abha. He published a number of articles such as (i) Multiple Functions of the Nunations in Arabic Syntax: A Minimalist Perspective. Dirasat, Human and Social Sciences, Vol. 36, No.3. 2009. and (ii) Assimilation of Segments in Modern Standard Arabic: Schane's (1973) Views on Generative Phonology. Dirasat, Human and Social Sciences, Vol. 38, No.1. January, 2011. Dirasat, Human and Social Sciences, Vol. 38, No.1. January, 2011.

Dr Jalabneh is currently a foreign coordinator for international affairs/ research center for Higher Studies in King Khalid University/ Saudi Arabia. 